\title{
Kematian Seutuhnya Dalam Pengakuan Gereja Toraja Menurut Pandangan
}

\section{Antropologi Metafisik}

\author{
Wandrio Salewa \\ Institut Agama Kristen Negeri (IAKN) Toraja \\ wandriosalewa72@gmail.com
}

\begin{abstract}
Death is a reality that every human being must experience. In death all human power and effort during his life becomes terminated, meaningless and death stops everything. Even so, humans believe in themselves there is something that is not affected by death, namely the soul, so that only the body experiences death. Whether influenced by philosophical thinking or traditional views. The dead body and the immortal soul contain the notion of a soul containing divine elements.

The description in this paper focus on understanding death as a whole using a metaphysical anthropology approach. With the research method of literature study and cursory observations, the result show that humans die completely and live completely. Humans experience death in both body and soul. However, on the other hand, in personal relationships with others, it is found that the body and soul remain intact in the memories of others, even though someone's person has died. The concept og human death as a whole, in the view of metaphysical anthropology, has similarities with complete death, is the recognition of the Toraja church.
\end{abstract}

Keywords: Death, Body, Spirit, Metaphysical Anthropology, Wholeness and Unity.

Abstrak: Kematian merupakan suatu realitas yang harus dialami setiap manusia. Dalam kematian semua daya dan upaya manusia selama hidupnya menjadi berakhir, tak bermakna lagi dan kematian menghentikan segalanya. Walaupun begitu, manusia meyakini dalam dirinya ada sesuatu yang tidak terpengaruh kepada kematian yaitu jiwa, sehingga hanya tubuh yang mengalami kematian. Entah terpengaruh oleh pemikiran filsafat atau pandangan tradisional. Tubuh mati dan jiwa baka berisi gagasan tentang jiwa yang mengandung unsur ilahi.

Uraian dalam tulisan ini berfokus pada memahami kematian seutuhnya menggunakan pendekatan antropologi metafisik. Dengan metode penelitian studi pustaka dan pengamatan sepintas sampai pada hasil bahwa manusia mati secara utuh dan hidup secara utuh. Manusia mengalami kematian baik tubuh maupun jiwanya. Namun, di sisi lain dalam relasi personal dengan sesama ditemukan bahwa tubuh dan jiwa tetap hidup secara utuh dalam ingatan orang lain, sekalipun pribadi seseorang telah meninggal. Konsep kematian manusia secara utuh dalam pandangan antropologi metafisik memiliki mirip dengan kematian seutuhnya dalam Pengakuan Gereja Toraja

Kata Kunci: Kematian, Tubuh, Jiwa, Antropologi Metafisik, Keutuhan dan Kesatuan.

Article History : $\quad$ Received: 06 November 2020 Revised: 29 Desember 2020 Accepted:30 Desember 2020




\section{Pendahuluan}

Gereja dari kata Yunani Ekklesia yang berarti rapat atau perkumpulan yang terdiri atas orang-orang yang dipanggil untuk berkumpul. Kata Yunani Ekklesia yang terdiri dari dua kombinasi kata yaitu $E k$ artinya keluar dan Kaleo artinya memanggil. Jadi Ekklesia menunjuk pada paguyuban yang memberi jawaban terhadap satu panggilan dengan cara keluar dari kelompok atau perhimpunan banyak orang. Arti ini berpadanan dengan pengertian asli kata ekklesia dalam bahasa Yunani, yakni rakyat yang dipanggil keluar dari rumah mereka masing-masing. ${ }^{1}$ Orang-orang yang dipanggil harus menyatakan kehendak Allah dalam dunia sesuai dengan pengakuannya dalam menerima keselamatan dalam Yesus Kristus. Setiap gereja pun memiliki pengakuan gereja atau pengakuan iman gereja yang menegaskan kepercayaan gereja kepada Yesus Kristus yang dirumuskan dan diputuskan dalam sidang sinode.

Pengakuan iman muncul seiring berkembangnya kekristenan, dan berbagai aliran kepercayaan yang menyesatkan iman orang Kristen serta pengakuan iman hadir untuk mengungkapkan pengakuan orang Kristen yang mereka percayai. Sehingga, bapabapa gereja dan para teolog membuat rumusan pengakuan iman untuk melawan berbagai aliran tersebut. Ada berbagai pengakuan iman yang berhasil dirumuskan dan disepakati menjadi sebuah pengakuan iman dalam sebuah gereja misalnya Pengakuan Iman Athanasius, Pengakuan Iman Rasuli, Pengakuan Iman Nicea-Konstantinopel, Pengakuan Iman Ausburg dan beberapa pengakuan iman lainnya. Setiap gereja pun mempercayai bahkan memiliki pengakuan iman sendiri. Seperti halnya dengan Gereja Toraja yang mempunyai pengakuan iman sendiri yang disebut sebagai Pengakuan Gereja Toraja (PGT). Gereja Toraja baru memiliki pengakuan iman sendiri dalam tahun 1981, walaupun jauh sebelum Gereja Toraja berdiri sebagai satu sinode, pengakuannya telah dibicarakan dari tahun $1930 .^{2}$

Pengakuan tersebut dilatarbelakangi oleh pergumulan panjang Gereja Toraja. Pengakuan tersebut beriintikan "Yesus Kristus Itulah Tuhan dan Juruselamat". Pengakuan Gereja Toraja yang terdiri dari delapan bab yaitu bab I (Tuhan Allah), bab II (Firman Allah), bab III (Manusia), bab IV (Penebusan), bab V (Pengudusan), bab VI (Umat Allah), bab VII (Dunia) dan bab VIII (Zaman Akhir). ${ }^{3}$ Dalam konsep manusia pada Pengakuan Gereja Toraja yang dicantumkan dalam Bab III Pengakuan Gereja Toraja (PGT). Konsep manusia dalam PGT dapat dibagi dalam pokok-pokok sebagai berikut: asal manusia, kehidupan manusia, kefanaan manusia dan keselamatan manusia.

Mengenai dimensi manusia, maka Gereja Toraja sudah mencantumkan secara nyata tentang manusia dalam Pengakuan Gereja Toraja. Gereja Toraja mengatakan Mulia), 40 .

1 Ebenhaizer I. Nuban Timo, Meng-Hari-Ini-Kan Injil di Bumi Pancasila (Jakarta: BPK Gunung

${ }^{2}$ Notulen Sidang Sinode Am XVI Gereja Toraja tahun 1981.

${ }^{3}$ Andarias Kabanga', Manusia Mati Seutuhnya (Yogyakarta: Media Pressindo, 2002), 247. 
"manusia diciptakan dalam kesatuan tubuh dan jiwa. Jiwa tidak ilahi dan tidak lebih penting daripada tubuh dan sebaliknya; oleh sebab itu, roh dan tubuh, hal rohani dan hal jasmani sama pentingnya. Manusia dipanggil memelihara tubuhnya sebagai bait Allah dalam kesucian". Dalam kaitan dengan konteks Toraja, dipercaya bahwa tubuh itu fana dan jiwa itu baka. Jiwa itu dibungkus oleh tubuh, dan sering keluar dari tubuh pada saat manusia tidur. Tubuh itu dikuasai oleh kematian, akan tetapi jiwa itu kekal. ${ }^{4}$

Pandangan itu agaknya sama dengan pemahaman sebagian warga Gereja Toraja dan Majelis Gereja. Hal ini kadangkala nampak dalam setiap khotbah dukacita dan pandangan mereka yang menganggap ketika manusia mati, tubuhnya akan hancur dan jiwanya akan kembali langsung kepada Tuhan, masuk surga ataupun berada pada sebuah tempat. Jiwa itu dianggap lebih tinggi atau lebih baik daripada tubuh, bahkan jiwa dianggap mengandung unsur ilahi sedangkan tubuh itu bersifat fana. Banyak warga Gereja Toraja termasuk Majelis Gereja yang tidak memahami dan bahkan keliru dalam menyampaikan dan mengerti tentang dimensi manusia dalam Pengakuan Gereja Toraja. Hal ini memunculkan persepsi atau pandangan yang berbeda di kalangan warga jemaat. Walaupun permasalahan ini sudah dikaji oleh Pdt Dr. Andarias Kabanga' dalam bukunya "Manusia Mati Seutuhnya" dengan menggunakan pendekatan antropologi Plato dan antropologi manusia Toraja, namun penulis ingin mengkaji permasalahan ini menggunakan pendekatan antropologi metafisik.

Antropologi ialah ilmu pengetahuan yang mempelajari tentang perkembangan dan asal-usul manusia. ${ }^{5}$ Sedangkan, metafisika ialah berbicara mengenai hal sesudah atau dibelakang realitas sesuai dengan etimologisnya. ${ }^{6}$ Sehingga, digunakan nama antropologi yang berasal dari sebuah kata Yunani yaitu anthropos yang artinya manusia dan kata ini dipakai untuk menyelidiki dan menunjukkan tentang manusia dalam arti positif. Antropologi metafisik juga berbicara dan menjelaskan keseluruhan manusia dari pandangan filsafat. Antropologi sebagai orientasi umum dan metafisik sebagai bagian khusus yang menggunakan metode metafisis. ${ }^{7}$ Pengkajian yang akan dilakukan oleh penulis tentang kematian seutuhnya menurut Pengakuan Gereja Toraja (PGT) untuk menjelaskan dan memberikan pemahaman baru tentang kematian seutuhnya melalui pandangan antropologi metafisik.

\section{Metode Penelitian}

Penelitian yang digunakan ialah metode kualitatif dengan studi pustaka dan pengamatan sepintas. Metode penelitian kualitatif adalah penelitian yang bermaksud

\footnotetext{
${ }^{4}$ Ibid., 249-258.

${ }^{5}$ Gunsu Nurmansyah, Pengantar Antropologi (Bandar Lampung: Aura, 2019), 3.

${ }^{6}$ Zulhelmi, "Metafisika Suhrawardi: Gradasi Esensi dan Kesadaran Diri," JIA: Jurnal Raden Fatah, no. 1 (Juni 2019): 102.

${ }^{7}$ Anton Baker, Antropologi Metafisik (Yogyakarta: Kanisius, 2008), 18.
} 
untuk memahami fenomena tentang apa yang dialami oleh subjek penelitian misalnya perilaku, persepsi, motivasi, tindakan, dan lain-lain. Secara holistik, dan dengan cara deskripsi dalam bentuk kata-kata dan bahasa, pada suatu konteks khusus yang alamiah dan dengan memanfaatkan berbagai metode alamiah. Kepustakaan harus dipakai sesuai dengan paradigma yang diikuti. Untuk paradigma post-positivis dan ancangan kualitatif, studi pustaka digunakan secara induktif dan bersifat eksploratori. Misalnya, dalam penelitian kualitatif berdasarkan teori, kepustakaan akan lebih banyak dipakai daripada dalam penelitian kualitatif untuk mendapatkan teori. Penelitian yang menggunakan teori, studi pustaka ditampilkan dibagian akhir, sebagai pembanding hasil penelitian. ${ }^{8}$ Sehingga dalam karya tulis ini menggunakan metode penelitian kualitatif dengan studi pustaka dan pengamatan sepintas tentang kematian seutuhnya dalam Pengakuan Gereja Toraja.

\section{Hasil dan Pembahasan}

\section{Pengertian Antropologi Metafisik}

Antropologi adalah salah satu cabang filsafat yang mempersoalkan hakikat dan sejarah manusia serta mempertanyakan keberadaannya, apakah manusia sedang sendiri, yang menjadi perenungan akan keberadaan dan kegelisahan dirinya. Pertanyaan mengenai hakikat manusia ialah pertanyaan yang paling tua sama dengan kehadiran manusia di dunia. Jawaban tentang manusia takkan pernah sampai tuntas dan menghasilkan jawaban final, yang tentunya disebabkan realitas di sekeliling manusia selalu baru, meskipun substansinya tak berubah. Menurut Van Peursen, metafisika adalah bagian dari filsafat yang memfokuskan kepada pertanyaan mengenai akar terdalam yang mendasari segala yang ada. ${ }^{9}$ Metafisika jika diartikan dari kata Inggris: metaphysics, Latin: metaphysica, dan dari kata Yunani meta ta physica (setelah fisika); meta (melebihi, setelah) dan physikos (menyangkut alam) atau physis (alam). ${ }^{10}$ Jadi metafisika ialah melebihi alam. Pengungkapan metafisika ini merupakan pandangan beberapa filsuf tentang metafisika yang melihat lebih jauh dan dalam tentang ide-ide yang menjadi hakikat sebuah realitas. Filsafat manusia berbicara tentang keseluruhan manusia, sehingga menggunakan kata antropologi. Kata antropologi untuk menunjukkan orientasi umum dan metafisik sebagai orientasi khusus yang menggunakan metode metafisis atau biasa juga disebut metode transedental. ${ }^{11}$

Antropologi metafisik melihat manusia dari keseluruhan dimensinya melalui filsafat dengan menggunakan metode metafisis. Pengkajian secara metafisik bukan untuk membuat menjadi lebih mengetahui, melainkan dapat mengungkapkan secara

\footnotetext{
${ }^{8}$ Andreas Bambang Subagyo, Pengantar Riset Kuantitatif Dan Kualitatif, 200.

9 Tumanggor, Raja Oloan \& Carolous Suharyanto, Pengantar Filsafat Untuk Psikologi (Yogyakarta: Kanisius, 2017), $181 \& 34$.

${ }^{10}$ Lorens Bagus, Kamus Filsafat (Jakarta: Gramedia Pustaka, n.d.), 623.

${ }^{11}$ Anton Baker, Antropologi Metafisik, 18.
} 
jelas, cermat dan mencegah kekeliruan. Penggunaan metode metafisik atau transedental yang dimulai dari kegiatan berbicara dan berpikir di dalam manusia ${ }^{12}$ serta berakhir pada sebuah refleksi metafisis.

\section{Manusia Menurut Alkitab}

Manusia (dalam bahasa Ibrani: 'adam), dibuat dari debu bumi, (bahasa Ibrani:'adama). Dalam Kejadian 2:7 disebutkan bahwa TUHAN Allah membentuk manusia dari debu tanah dan menghembuskan nafas hidup ke dalam hidungnya; demikianlah manusia menjadi makhluk hidup. Ayat ini pertama-tama menunjukkan bahwa manusia bukanlah berada dengan dirinya sendiri, melainkan bahwa ada yang menciptakannya, yaitu Tuhan Allah sendiri. Tuhan Allahlah yang menciptakan manusia yang semula belum ada, sehingga menjadi ada. Jadi manusia ada karena kehendak Allah (bnd. Kej.1:26). Manusia bukanlah keturunan Allah, manusia juga bukan mengalir keluar daripada Allah, tetapi diciptakan oleh Allah. ${ }^{13}$

Melalui Kejadian 1:26 memberikan gambaran bahwa cara Tuhan Allah menjadikan atau menciptakan manusia berbeda sekali dengan caranya menciptakan makhluk-makhluk yang lain. Manusia adalah makhluk yang ada karena diciptakan oleh Tuhan Allah. Manusia adalah hasil karya Allah, yang keadaannya berbeda sekali dengan Tuhan Allah sang penciptanya. Di Kej. 2:7 manusia diciptakan dari debu tanah, yang ke dalamnya dihembuskan nafas hidup. Daging atau debu tanah sebagai badan atau tubuh manusia, penampakan atau bentuk manusia yang lahiriah, sisi kodrati manusia atau sisi keduniawian (bnd. Yoh.1:13; 3:5; 1 Yoh. 2:16), yang menciptakan manusia sebagai makhluk yang sangat berbeda dengan Tuhan Allah Khaliknya. Ada dua tahapan menciptakan, tapi hasilnya ialah tunggal yaitu manusia hidup dalam kesatuan. Unsur tanah ialah sebagian kebendaan sedangkan nafas Allah memberikan kehidupan. Penggabungan unsur yang benda dengan yang bukan benda menghasilkan keberadaan manunggal atau kelihatan dan tak kelihatan yang dipersatukan. Dalam unsur kebendaan terdapat berbagai bentuk rambut, otot, otak, saluran darah dan lain-lain. Unsur bukan kebendaan beragam pula adanya seperti jiwa, roh, hati nurani, kemauan, kesadaran dan lain-lain. Tetapi tanpa kesatuan dari seluruh keberadaan tersebut, masing-masing tak akan dapat berfungsi.

Pandangan Alkitab mengenai manusia menunjukkan kemajemukan yang mengesankan dan Alkitab tak pernah kehilangan pandangan bahwa manusia merupakan satu kesatuan dari keseluruhan. Bahkan Alkitab menampilkan serta menekankan satu kesatuan. Manusia terdiri dari dua bagian sebagai suatu hakikat yang tak dapat

12 Ibid, 17.

${ }^{13}$ Charles C. Ryre, Teologi Dasar 1 Panduan Populer Untuk Memahami Kebenaran Alkitab (Yogyakarta: Andi, 2015), 285. 
disangkal. Manusia adalah kesatuan materi dan bukan materi, dua aspek yang dapat dibedakan. ${ }^{14}$ Debu tanah atau daging terbatas hidupnya, dapat rusak (Yes. 31:3) dan juga lemah (Mzm. 56:5; 78:31). Demikian debu tanah atau daging tak memiliki hidup di dalam dirinya. Debu tanah dan daging hanya bisa hidup selama Tuhan Allah memberikan hidup kepadanya (Kej. 6:1,3). ${ }^{15}$ Tubuh dalam Alkitab tidak hanya dipandang sebagai lawan, isi dan bentuk. Namun, tubuh juga sebagai cara berada manusia yang secara asasi dan konstitutip. Manusia tak dapat dipisahkan daripada tubuhnya. Membicarakan manusia itu sendiri berarti keseluruhan dan keutuhan manusia (bnd. 1 Kor. 15:35). Kodrat insani atau tabiat manusia secara nyata dan jelas diungkapkan dalam tubuh jasmaninya yang mewujudkan suatu kesatuan harmonis dengan segala bagian-bagiannya (Bnd. Mat. 5:30; 6:25; Rm. 12:4). Badan atau tubuh sebagai penampakan pribadi manusia seluruhnya. Manusia tak mungkin berada tanpa tubuh. Badan atau tubuh adalah bagian yang asasi dari manusia. Manusia juga dapat disebut dengan tubuhnya saja. 16

Pandangan bahwa tubuh bersifat duniawi dan jiwa bersifat ilahi tidak sesuai dengan inti Alkitab di dalam diri manusia membedakan antara bagian jasmani, yang dianggap duniawi dan bagian rohani, yang dianggap ilahi berasal dari tradisi lain. Di dalam Alkitab tidak terdapat wawasan jiwa yang kekal. Sebagai makhluk yang diciptakan, manusia tetap bergantung pada nafas Allah. Tidak unsur dalam diri manusia yang menjamin kehidupannya, apalagi kekekalannya. Manusia adalah satu kesatuan yang terdiri atas dua dimensi yakni dimensi jasmani di satu pihak dan dimensi rohani dipihak lain. Kemudian, tubuh di satu pihak lain dan jiwa atau roh dipihak lain merupakan suatu kesatuan yang tak dapat terpisahkan.

Lebih tegas lagi, manusia tidak mempunyai tubuh, seakan-akan manusia adalah jiwa yang mempunyai tubuh. Kalau begitu maka manusia yang sesungguhnya adalah jiwa dan kepada jiwa ini diberikan tubuh, semacam pakaian saja. Tubuh hanya menyangkut yang lahiriah. Pandangan ini juga tidak Alkitabiah. Sebaliknya dapat dikatakan, manusia adalah tubuh dan manusia adalah jiwa. Tubuh adalah manusia secara menyeluruh, karena tubuh itu adalah tubuh yang dijiwai oleh jiwa. Begitu pula, jiwa adalah manusia secara menyeluruh, karena jiwa itu adalah jiwa yang ditubuhi oleh tubuh. Tubuh tanpa jiwa sama dengan mayat. Jiwa tanpa tubuh paling banter merupakan hantu yang mengerikan. Dengan kata lain, jiwa tanpa tubuh sama matinya seperti tubuh tanpa jiwa. Kalau mau membedakan juga antara tubuh dan jiwa, lebih baik dikatakan, tubuh dan jiwa merupakan dua aspek manusia. ${ }^{17}$

Pandangan Alkitab tentang manusia jelas menganggap manusia sebagai kesatuan yang utuh. Alkitab dengan berbagai penjelasan dari atas tetap mengakui bahwa manusia

\footnotetext{
${ }^{14}$ Ibid, 14.

${ }^{15}$ Hadiwijono, Iman Kristen, 173.

${ }^{16}$ Ibid, 173-174.

${ }^{17}$ Plaiser, Manusia Gambar Allah, 45-47.
} 
adalah kesatuan tubuh dan jiwa atau kesatuan tubuh, jiwa dan roh yang utuh serta tidak berdiri sendiri. Jiwa tidak lebih penting dan lebih baik dari tubuh maupun sebaliknya.

\section{Kematian Seutuhnya Dalam Pengakuan Gereja Toraja}

Dalam dimensi manusia, maka Pengakuan Gereja Toraja sudah mencantumkannya secara nyata mengenai manusia. Pengakuan Gereja Toraja mengatakan; "Manusia diciptakan dalam kesatuan tubuh dan jiwa. Jiwa tidak ilahi dan tidak lebih penting daripada tubuh dan sebaliknya; oleh sebab itu, roh dan tubuh, hal rohani dan hal jasmani sama pentingnya. Manusia dipanggil memelihara tubuhnya sebagai bait Allah dalam kesucian". Pengakuan Gereja Toraja menyatakan dengan tegas bahwa jiwa itu sama pentingnya tubuh, dan jiwa itu tidak mengandung unsur ilahi. Dengan demikian kepercayaan, Kristen sebagaimana yang dipahami oleh Gereja Toraja sangat berbeda dari persepsi yang ada dalam kepercayaan tradisional Toraja.

Dalam Kejadian 2:7 dikatakan Tuhan membentuk manusia dari debu tanah dan menghembuskan nafas hidup ke dalam hidungnya. Tuhan menghembuskan nafas hidup ke dalam hidung manusia, adalah "cara" yang Tuhan tempuh untuk menjadikan manusia sebagai makhluk yang hidup, yang berpikir dan mempunyai perasaan. Bila Tuhan menghembuskan nafas hidup ke dalam hidung manusia maka menurut paham Gereja Toraja hal itu tidak berarti bahwa Allah memasukkan sebagian dari hakikatnya ke dalam diri manusia, sehingga manusia mengandung unsur ilahi, melainkan Allah menciptakan daya hidup bagi manusia. Jiwa manusia bukanlah unsur ilahi atau sebagian ilahi, melainkan tidak ilahi. ${ }^{18}$

Bagi gereja Toraja memandang manusia adalah kesatuan tubuh dan jiwa. Manusia tidak dapat disebut manusia, jika tak memiliki tubuh dan manusia juga tak disebut manusia, jika tak memiliki jiwa yang menjiwainya. Kehilangan dari salah satu unsur ini, bukankah sebuah kondisi cacat sebagai manusia. Pentingnya melihat manusia dalam sebuah kesatuan walaupun sumber tubuh dan jiwa adalah jelas berbeda, tetapi kedua hal itu tidak bisa dihilangkan atau dihapuskan, bahkan menganggap salah satunya lebih baik. Manusia ialah kesatuan sekaligus dua. Suatu kesatuan namun memiliki dua kenyataan yang bertentangan. ${ }^{19}$

Gereja Toraja telah merumuskan kematian seutuhnya sebagai suara kenabiannya dengan mengandung lima makna yaitu: pertama, dengan ungkapan manusia mati seutuhnya, maka setiap paham tentang adanya immortalitas jiwa orang-orang yang telah meninggal dilawan dengan tegas. Kedua, dengan adanya formulasi itu, maka setiap upaya untuk menggantungkan kehidupan ini dari nenek moyang dihilangkan. Bukan

\footnotetext{
${ }^{18}$ Kabanga', Manusia Mati Seutuhnya, 258-259.

${ }^{19}$ Adelbert Snijders, Antropologi Filsafat Manusia Paradoks dan Seruan, (Yogyakarta: Kanisius, 2019), 105.
} 
leluhur yang menentukan hidup ini, melainkan Yesus Kristus. Ketiga, dengan kematian seutuhnya harus diakui bahwa manusia hidup bukan dari dirinya sendiri, tetapi sematamata dari anugerah Allah dalam Yesus Kristus. Keempat, Gereja Toraja hendak menyatakan sikapnya terhadap ilmu pengetahuan khususnya filsafat bahwa manusia adalah makhluk Tuhan yang fana. Kelima, warga Gereja Toraja menyatakan imannya ditengah-tengah pluralitas agama yang ada bahwa manusia adalah suatu totalitas. ${ }^{20}$

Dengan melihat makna yang ada dalam Pengakuan Gereja Toraja bila dikaitkan dengan lingkungan Toraja seperti pengaruh adat budaya Toraja, kepercayaan tradisional Toraja, kemajemukan agama yang ada di Indonesia, perjumpaannya dengan dunia modern, maka dapat dikatakan bahwa Pengakuan Gereja Toraja bersifat Alkitabiah dan kontekstual. ${ }^{21}$

\section{Asal Usul Manusia Menurut Antropologi Metafisik}

Kelahiran manusia bisa digambarkan menggunakan pengertian kelahiran substansi-substansi infrahuman yang dianggap material seperti pada pohon atau hewan. Pengandaian tentang serba substansi infrahuman (hanya jasmani) yang lebih dipahami daripada manusia sehingga, membutuhkan keterangan tambahan terhadap bagian kerohanian manusia. Namun, dualisme mengenai asal material dan spiritual manusia mustahil terjadi sebab kesatuan jiwa dan tubuh manusia. Ini mutlak terjadi dalam kegiatan orang tua dan kepada anak yang dilahirkannya. Kelahiran manusia sebagai substansi kelahiran otonom baru. Kelahiran substansi infrahuman dapat menimbulkan insight hakiki mengenai manusia, dengan pemahaman tentang hakikat manusia sehingga membuka jalan terhadap pengertian kelahiran yang bersifat fundamental. Ada beberapa pandangan berkaitan asal usul manusia seperti dua ekstrem (materialisme dan spiritualisme panteistis), dualisme dan tradusianisme. Keempat aliran ini memiliki pandangan yang berbeda-beda tentang asal-usul manusia.

Dalam pandangan materialisme keseluruhan manusia adalah materi dan seluruhnya manusia dilahirkan dari orang tuanya berdasarkan proses yang alami. Dapat dikatakan manusia hanya materi yang diturunkan dari orang tua kepada anaknya. Sedangkan pandangan spiritualisme panteistis jiwa berasal dari substansi ilahi, entah berada sebagai preeksistensi atau hasil modifikasi dari fase yang terjadi dari substansi ilahi. Tubuh sebagai epifenomena dari jiwa. Dualisme mengatakan jiwa diciptakan sebagai substansi utuh dalam preeksistensi atau sudah ada sebelum kehidupan duniawi. Lalu, jiwa dipersatukan dengan tubuh dan tentunya memiliki berbagai penyebab. ${ }^{22}$ Dalam pandangan dualisme, jiwa dan tubuh berarti sesuatu pemisahan jiwa dan tubuh berdiri sendiri pada awalnya. Lalu dipersatukan dalam diri manusia yang membuat

\footnotetext{
${ }^{20}$ Kabanga', Manusia Mati Seutuhnya, 359.

${ }^{21}$ Ibid, 359.

${ }^{22}$ Baker, Antropologi Metafisik, 281-283.
} 
ketika manusia mati, tubuh dan jiwanya berpisah.

Ada pandangan lain yang berusaha mensintesiskan antara dua ekstrem (materialisme dan spiritualisme) dengan dualisme yaitu tradusianisme. Tradusianisme yang asal katanya latin yaitu traducere yang berarti memberi alih atau menyerahkan baik tubuh maupun jiwa yang dilahirkan orang tua atau peralihan dari substansi orang tua. Ada dua macam tradusianisme yaitu tradusianisme materiil dan tradusianisme spiritual. ${ }^{23}$ Sekalipun ada berbagai pandangan tentang asal usul manusia seperti dualisme ekstrem, dualisme dan tradusianisme. Akan tetapi, penulis memandang asal usul manusia sebagai keutuhan peralihan yang diwarisi dari orang tuanya, baik tubuh dan jiwanya. Sebab, terdapat gambaran bahwa materi maupun spiritual dalam seorang anak, keduanya berasal dari orangtua dan saling berhubungan. Bahkan sejak dari kandungan.

\section{Hakikat Manusia}

Manusia adalah makhluk multidimensional yang memiliki tiga dimensi (tubuh, jiwa atau roh). Unsur pokok yang membentuk manusia selalu berkaitan dengan hakikat manusia. ${ }^{24}$ Itulah sebabnya, penting membahas asal usul manusia, hakikatnya dan sampai pada kematian manusia. Dalam diri manusia terdapat tubuh, jiwa atau roh. Tubuhnya termasuk dunia-benda, jiwanya termasuk dunia makhluk hidup dan rohnya bertransendensi terhadap dunia benda dan dunia makhluk hidup. ${ }^{25}$ Dalam bagian hakikat manusia dibagi dua yaitu tubuh (badan) dan jiwa (roh), sebab roh dianggap sama saja dengan jiwa sebagai dua unsur yang tak terlihat.

Dalam filsafat manusia yang berbicara tentang hakikat manusia dalam hal ini tubuh dan jiwa, yang kemudian diartikan sebagai materi dan spiritual. Aliran filsafat manusia tentang kedudukan tubuh dan jiwa dilihat secara berbeda yang memunculkan pertentangan antara aliran monisme dan dualisme. ${ }^{26}$ Pada bagian ini, penulis menggunakan konsep monisme dan dualisme untuk melihat hubungan dan kedudukan tubuh dan jiwa. Berikut uraian tentang aliran monisme dan dualisme:

\section{Monisme}

Monisme merupakan aliran filsafat yang menolak pandangan tubuh dan jiwa merupakan dua unsur terpisah. Aliran ini mengatakan bahwa tubuh dan jiwa merupakan suatu substansi keduanya yang merupakan kesatuan yang membentuk kepribadian manusia. Aliran monisme memiliki tiga bentuk yakni materialisme, teori

23 Ibid, 283.

24 Tumanggor, Raja Oloan \& Carolous Suharyanto, Pengantar Filsafat Untuk Psikologi (Yogyakarta: Kanisius, 2017), 182.

${ }^{25}$ Snijders, Antropologi Filsafat Manusia Paradoks dan Seruan, 161.

${ }^{26}$ Tumanggor \& Suharyanto, Pengantar Filsafat Untuk Psikologi, 210. 
identitas dan idealisme (spritualisme).

Materialisme sebagai teori yang tertua dalam membicarakan hubungan tubuh dan jiwa serta materi ditempatkan sebagai dasarnya. Materialisme antropologis muncul dalam dua bentuk yaitu materialisme yang membantah adanya jiwa. Jiwa sama dengan materi dan tentunya materi mempunyai perubahan-perubahan fisik-kimiawi, menyangkal adanya ketidaktergantungan eksistensi jiwa pada materi. ${ }^{27}$ Jelaslah bahwa materialisme hanya mengakui unsur materi yaitu tubuh dan menyangkali keberadaan spiritual yaitu jiwa. Materi (tubuh) adalah paling awal dan dalam serta nyata. Sehingga, materi dapat bereksistensi sebab mempunyai kekuatan tanpa gerakan dan dukungan dari bukan materi. Materi sebagai keterangan, sumber terdalam dan segalanya bergantung kepada materi. Materialisme meyakini esensi manusia bersifat materi atau fisik ciri utama dari kenyataan fisik atau material dapat menempati ruang dan waktu memiliki keluasan (res extensa) dan bersifat objektif. Jiwa atau alam spiritual tidak dapat dikatakan esensi kenyataan sebab tidak menempati ruang sehingga, ditolak keberadaannya. ${ }^{28}$

Berdasarkan konsep materialistik, manusia terdiri dari unsur-unsur materi, sedangkan kehidupan mental, emosional, dan rohnya hanya merupakan hasil atau efek samping dari struktur materialnya. ${ }^{29}$ Materi ialah hasil terakhir dan sebagai hasil evolusi paling tinggi. ${ }^{30}$ Pemahaman materialisme mereduksi aktivitas mental (jiwa) ke dalam materi (tubuh), sehingga jiwa tidak berdiri sendiri melainkan bersumber dari materi (tubuh). Namun, materialisme mengalami kesulitan dalam menjelaskan ketika jari seseorang teriris pisau sebab bukan hanya tubuh yang adalah materi merasakan sakit tapi jiwanya juga mengalami kesakitan. Materi atau tubuh tidak bisa berada dan menyatakan eksistensinya tanpa jiwa. Jiwa memang tidak kelihatan, karena jiwa ialah rex cogitans (kegiatan berpikir) tetapi jiwa menggunakan tubuh (rex extensa) yang berkeluasan untuk menyatakan eksistensinya. Tubuh dan jiwa merupakan dua kenyataan dalam diri manusia yang saling melengkapi untuk menyatakan eksistensi sebagai manusia yang utuh.

Teori identitas menekankan bahwa aktivitas mental merupakan identitas manusia dan membedakan manusia dengan makhluk yang lain. Manusia dibedakan dengan cara filosofis berdasarkan referensi dan arti atau denotasi dan konotasi. Aktivitas fisik dan mental tidak berbeda secara mendasar namun, hanya berbeda dalam arti atau konotasi tetapi dari empirisme menunjuk pada objek atau gejala yang sama. Dengan demikian, teori identitas meletakkan perbedaan jiwa dan tubuh hanya kepada arti bukan dalam referensi serta tubuh dan jiwa merupakan dua elemen yang sama ${ }^{31}$

${ }^{27}$ Lorens Bagus, Kamus Filsafaf (Jakarta: Gramedia Pustaka Utama, n.d.), 597.

${ }^{28}$ Zainal Abidin, Filsafat Manusia (Bandung: Remaja Rosdakarya, 2011), 25.

${ }^{29}$ Anthony A Hoekema, Manusia Ciptaan Menurut Gambar Allah (Surabaya: momentum, 2000), 3.

${ }^{30}$ Kasdin Sihotang, Filsafat Manusia (Yogyakarta: Kanisius, 2009), 50.

${ }^{31}$ Ibid., 51. 
atau tubuh dan jiwa memang dilihat berbeda, tetapi tidak secara substansial, melainkan hanya pada artinya. ${ }^{32}$

Aktivitas mental (jiwa) sebagai identitas manusia sebagai yang utama sebab inilah letak perbedaan manusia dengan makhluk lain. Pernyataan mental dan fisik manusia ialah sama dalam substansi, sumbernya dan secara empiris menunjuk pada gejala atau objek yang sama tetapi, berbeda dalam arti. Aktivitas mental (jiwa) dan aktivitas fisik (tubuh) tidak serta merta selalu disamakan. Ada kalanya aktivitas mental berjalan sendiri dalam res cogitans atau kegiatan berpikir manusia dan aktivitas fisik berjalan sendiri dalam empirisme, sebab aktivitas fisik ialah res extensa yang memiliki keluasan. Baik aktivitas mental dan aktivitas fisik berbeda, namun keduanya saling berhubungan dan membutuhkan untuk menyatakan eksistensi manusia. Sebab, aktivitas mental membutuhkan aktivitas fisik untuk menyatakan apa yang akan dilakukan oleh aktivitas mental dan itu terlihat melalui aktivitas fisik.

Idealisme digunakan untuk memperlihatkan filsafat yang melihat ideasional atau mental sebagai kunci masuk ke hakikat realitas. Gejala psikis yakni roh, ide, pikiran mutlak dan pikiran-pikiran sebagai jalan dalam menjelaskan sebauh realitas yang tidak berkaitan dengan materi. ${ }^{33}$ Idealisme disebut juga spiritualisme karena kenyataan sejati adalah bersifat spiritual yang berhubungan dengan roh dan pikiran serta ide. Idealisme mendasarkan sesuatu di luar materi. Spiritualisme kebalikan dari materialisme. Spiritualisme melihat sesuatu yang mendasar pada diri manusia adalah hal-hal yang tak bisa dijelaskan hanya berdasarkan pada materi seperti nilai, pengalaman dan makna. Penganut Spiritualisme percaya bahwa ada kekuatan atau kenyataan spiritual di balik setiap penampakan atau kejadian. ${ }^{34}$ Setiap kejadian atau penampakan selalu dipercaya bahwa ada kekuatan yang lain dan mendasar dari penyebab terjadinya sebuah kejadian atau penampakan. Kekuatan yang mendasar ini disebut sebagai kekuatan spiritual. Karena spiritual adalah penyebab atau sumbernya, sehingga dianggap sebagai yang utama dan mendasar dalam sebuah kenyataan.

Esensi spiritual ialah berpikir (res cogitans). Sebab, spiritual tidak bisa dijelaskan apalagi diukur sebagai pengamatan empiris, maka digunakan metafor-metafor kesadaran manusia. Kekuatan spiritual dianggap bersifat rasional, berkehendak, berperasaan, kreatif dan lain-lain. Fungsi metafor kesadaran manusia untuk menjelaskan kenyataan sejati yang ada di balik penampakan lahiriah. Namun, para idealis tidak menolak kekuatan-kekuatan yang bersifat fisik (material) dan menolak adanya hukum alam. ${ }^{35}$ Seperti halnya, penampakan atau kejadian empiris yang

${ }^{32}$ Yeremias Jena, Wacana Tubuh Dan Kedokteran Sebuah Refleksi (Jakarta: Universitas Katolik Atma Jaya, 2019), 1.

${ }^{33}$ Bagus, Kamus Filsafat, 300.

${ }^{34}$ Abidin, Filsafat Manusia, 27.

${ }^{35}$ Abidin, Filsafat Manusia, 27-28 
dilakukan manusia merupakan manifestasi lahiriah dari jiwa manusia. Perilaku atau tindakan manusia mempunyai tujuan dan maksud tertentu, bukan bergerak dengan sendirinya atau berasal dari kekuatan eksternal. Namun, bersumber dari kekuatan internal yakni jiwa, yang hendak menyatakan eksistensinya melalui tubuh.

Dualisme

Menurut aliran dualisme kenyataan sejati dasarnya ialah baik bersifat fisik maupun spiritual. Sebab, banyak kejadian di dunia ini, yang tidak bisa dijelaskan berdasarkan pengamatan pancaindera dan tidak bisa juga menyangkal keberadaan dan kekuatan yang nyata dari materi. Kenyataan sejati ialah perpaduan antara materi dan roh yang merupakan esensi manusia. Manusia adalah makhluk yang terdiri dari dua substansi yakni materi dan roh atau tubuh dan jiwa. ${ }^{36}$ Dalam bagian ini, dualisme mempunyai empat cabang yaitu interaksionisme, okkasionalisme, paralelisme dan epifenomenalisme.

Interaksionisme berfokus pada hubungan timbal balik antara tubuh dan jiwa. Aliran ini mengakui bahwa peristiwa mental kadangkala menimbulkan peristiwa badaniah, sebaliknya peristiwa badaniah kadangkala menimbulkan peristiwa mental. ${ }^{37}$ Ini juga disebut teori interaksi bahwa daya berpikir dan motor organisme mempunyai hubungan timbal balik yang saling mendukung dan berhubungan. ${ }^{38}$ Teori ini, hasil interpretasi manusia dengan pikiran (mind) berhasil memunculkan interaksi dengan menggunakan simbol. Simbol yang dimaksudkan ialah bahasa verbal maupun nonverbal.

Pikiran manusia melibatkan kegiatan mental dan menempatkan dirinya sehingga mampu menafsirkan makna dan arti dari sebuah pikiran yang tepat dengan menggunakan simbol dalam hubungan dengan orang lain. Melalui akalnya, manusia bisa mengekspresikan apa saja yang di deteksinya sebagai sesuatu yang rasional dan logis serta bersifat empiris dalam kehidupan kesehariannya. ${ }^{39}$ Misalnya ketika manusia jatuh dan kepalanya terbentur, memungkinkan baginya untuk kehilangan kesadaran ataupun secangkir kopi pahit membuat yang meminumnya merasakan pahit dan menyimpulkan bahwa kopi itu pahit. Dari hal ini, hubungan akal atau pikiran (jiwa) dengan tubuh nampak dan saling mempengaruhi, sehingga terlihat jiwa dan tubuh saling membutuhkan untuk menyatakan eksistensi manusia secara utuh. Walaupun sifat jiwa dan tubuh berbeda.

Okasionalisme berasal dari kata occasio yang berarti kesempatan dan aliran ini dipelopori oleh Nicolas Malebranche (1638-1715). Okasionalisme mengatakan bahwa jiwa tidak mempunyai pengaruh atas tubuh dan sebaliknya tubuh tidak dapat

\footnotetext{
${ }^{36}$ Ibid, 30.

${ }^{37}$ Sihotang, Filsafat Manusia, 53.

${ }^{38}$ Sudarsono, Kamus Filsafat dan Psikologi (Jakarta: Rineka Cipta, 1993), 119.

${ }^{39}$ Hamidulloh Ibda, Filsafat Umum Zaman Now (Pati: Kataba Grup, 2018), 97.
} 
mempengaruhi jiwa. Tetapi pada kesempatan terjadinya perubahan dalam tubuh, Allah menyebabkan perubahan yang sesuai dengannya dalam jiwa maupun sebaliknya. ${ }^{40}$ Hanya Allah yang memiliki satu-satunya aktivitas real dan intervensi Allah secara langsung yang terbatas hanya penyebab dan bersifat okasional dalam aktivitas Allah. Adanya kaulitas efisien pada sesuatu yang terbatas ditolak keberadaannya. Kausalitas dalam hubungan timbal balik jiwa dan tubuh ditolak. ${ }^{41}$

Dunia rohaniah tidak langsung mempengaruhi dunia jasmaniah, begitu juga sebaliknya. Namun, kedua dunia ini berjalan paralel dalam diri manusia sebagai kesatuan berkat Allah sebagai penyebab pertama (pencipta) segala ciptaan. ${ }^{42}$ Penekanannya pada dimensi ilahi dalam menjelaskan hubungan tubuh dan jiwa. Allah dianggap memiliki campur tangan dalam hubungan antara peristiwa mental dan peristiwa fisik. Allah selalu menemukan kesempatan dalam menyesuaikan antara mental dan fisik. ${ }^{43}$

Paralelisme menyetarakaan kejadian yang ragawi dan yang rohani. Aliran ini menyatakan bahwa sistem kejadian ragawi terdapat di alam, sedangkan sistem kejadian kejiwaan terdapat dalam jiwa manusia di antara keduanya tidak ada hubungan sebab akibat. ${ }^{44}$ Baik keduanya berjalan berdasarkan sistemnya sendiri-sendiri yang ditentukan sejak semula atau keserasian yang sudah diciptakan Tuhan sebelumnya (preestablished harmony). ${ }^{45}$ Bagaikan dua rel kereta yang sejajar dan dilalui kereta, kelihatannya berjalan bersama namun tidak saling mempengaruhi dan berhubungan. Pengandaian ini tidak begitu tepat, sebab ada kejadian atau penampakan dari keberadaan manusia yang memperlihatkan hubungan tubuh dan jiwa. Sebab dapatkah diterima sakit gigi yang dialami seseorang, tidak mempengaruhi semangatnya? Tentu tidak, rasa sakit yang dirasakannya mempengaruhi semangat dan caranya menjalani kehidupannya. Di sinilah terlihat adanya hubungan jiwa dengan tubuh.

Epifenomenalisme ialah aliran yang mendasarkan hubungan tubuh dan jiwa dalam fungsi saraf, aliran ini menerangkan jika unsur yang didapatkan untuk menyelidiki proses-proses kejiwaan ialah syaraf manusia. ${ }^{46}$ Epifenomenalisme berpandangan bahwa kejadian mental disebabkan oleh kejadian fisik di otak, namun tidak berpengaruh terhadap kejadian fisik apapun. ${ }^{47}$ Kesadaran syaraf-syaraf manusia sebagai satu-satunya unsur yang ditemui dari penyelidikan proses-proses kejiwaan. Kesadaran sebagai hasil sampingan dari proses syaraf namun, kesadaran tidak

\footnotetext{
${ }^{40}$ K. Bertens, Ringkasan Sejarah Filsafat (Yogyakarta: Kanisius, 2012), 50.

${ }^{41}$ Bagus, Kamus Filsafat, 736.

${ }^{42}$ Snijders, Antropologi Filsafat Manusia Paradoks dan Seruan, 121.

${ }^{43}$ Sihontang, Filsafat Manusia, 54.

${ }^{44}$ Ibid, 54.

45 Ibda, Filsafat Umum Zaman Now, 99.

${ }^{46}$ Sihontang, Filsafat Manusia, 54.

${ }^{47}$ Alo Liweri, Prasangka, Konflik, dan Komunikasi Antarbudaya (Jakarta: Kencana, 2018), 582.
} 
mempengaruhi proses-proses yang terjadi. Diandaikan hubungan nyala cahaya dengan hangatnya pijar bola lampu listrik. Penting untuk memperhatikan, ada perbedaan antara jiwa sebagai proses-proses syaraf dan jiwa sebagai hasil sampingan dari proses-proses syaraf. Perbedaan dapat diandaikan dengan mengatakan cahaya itu listrik dan cahaya merupakan akibat arus listrik. Proses-proses kejiwaan, khususnya kesadaran hendaknya dilihat sebagai nyala yang berasal dari proses-proses syaraf. ${ }^{48}$

Akhirnya dari hubungan dan kedudukan tubuh dan jiwa sebagai hakikat manusia menggunakan konsep monisme dan dualisme ditemukan bahwa tubuh dan jiwa yang membentuk manusia sebagai 'aku' (manusia utuh) dan keberadaan tubuh dan jiwa sangat penting serta harus diakui keberadaannya. Karena, tubuh tidak bisa berada sendiri atau yang utama dalam diri manusia tanpa jiwa, begitupun sebaliknya. Tubuh membutuhkan jiwa untuk mengarahkannya dalam bertindak dan terlihat dari perbuatan yang dilakukan oleh tubuh. Begitu juga dengan jiwa yang membutuhkan tubuh untuk menyatakan apa yang dikehendaki oleh jiwa, sehingga kehendak dari jiwa nyata dalam sebuah perbuatan yang dilakukan oleh tubuh. Penulis melihat hubungan dan kedudukan tubuh dan jiwa dalam diri manusia sejajar yang berkerjasama untuk menyatakan eksistensi manusia yang utuh. Sehingga, penulis menganggap manusia sebagai sebuah keutuhan. Boleh dibedakan aspek tubuh dan jiwa tetapi melihat manusia dari konsep 'aku' atau manusia yang utuh.

Penulis tidak memihak pada konsep monisme atau dualisme. Dari kedua konsep ini digunakan untuk melihat lebih jauh hubungan dan kedudukan tubuh dan jiwa dalam diri manusia. Hal inilah yang membuat penulis berpikir bahwa manusia sebagai sebuah keutuhan. Sebab, aspek tubuh dan jiwa tidak bisa berada sendiri, justru saling membutuhkan dan berkolaborasi menyatakan eksistensi manusia serta kehilangan salah satu unsur, baik tubuh maupun jiwa, tidakkah itu kondisi yang cacat sebagai manusia. Sangat penting untuk melihat manusia sebagai sebuah keutuhan.

${ }^{48}$ Bagus, Kamus Filsafat, 211. 


\section{Kematian Manusia}

Kematian merupakan akhir dari sebuah perjalanan hidup manusia dan setiap manusia pada akhirnya mengalami kematian. Penyakit, luka atau usia tua tidak memampukan manusia, sehingga hidup harus berakhir. Manusia mengetahui bahwa dirinya akan mengalami kematian dan menghayati hidup seraya menghadapi maut, Dobzhansky menyebutnya kesadaran kematian. Heidegger mengajarkan bahwa kematian yang memungkinkan kehidupan memiliki makna. Kehidupan manusia hanya memiliki nilai dan kesatuan apabila ada akhir hidup atau suatu batas yang memberi perspektif. Kematian adalah faktor asasi dalam eksistensi manusia yang terbatas. Setiap bayi yang lahir sudah berada di jalan kematian. Eksistensi manusia disebut Sein-zumTode, ada menuju kematian. ${ }^{49}$ Menurut filsafat, ada dua jenis kematian yaitu kematian dari segi negatif dan kematian dari segi postif.

Kematian sebagai berakhirnya kehidupan atau berhentinya makhluk (cessation vitae atau cessation entis viventis). Kematian ini dalam hakikatnya diartikan serba negatif sehingga kematian ini disebut kematian segi negatif. ${ }^{50}$ Sebab, bukan hanya tubuh yang meninggal, melainkan seluruh manusia (tubuh dan jiwa) sampai inti sari eksistensinya yang mengalami kematian yang dapat dikatakan manusia mengalami kematian secara total, Jiwa-tubuh itu sejajar, tidak ada yang lebih rendah atau lemah dari yang lainnya. Kesatuan substansi manusia tidak mengizinkan pemisahan antara badan yang harus meninggal dan binasa, dan jiwa yang tidak dapat meninggal dan bersifat transenden. ${ }^{51}$ Manusia juga satu di dalam kematiannya, tidak ada aspek dalam diri manusia yang terhindar dari kematian. Selain daripada ingatan tentangnya dalam relasi aku-engkau yang tersimpan baik karena cinta.

Dalam kematian segi positif, manusia mempunyai harapan setelah kematian yang disebut keabadian melalui proses kristalisasi. Seluruh manusia 'aku' sampai kepada kristalisasi, tidak hanya jiwa, melainkan juga tubuh abadi (immortal). Sebab manusia ialah jiwa yang ditubuhi dan tubuh yang dijiwai. Jiwa-tubuh selalu sejajar ${ }^{52}$ sehingga, nampaklah sebuah keutuhan manusia dalam proses kristalisasi. Tidak ada yang lebih baik maupun penting dari dua aspek manusia. Manusia mencapai realisasi keunikannya hanya karena perwujudan yang terjadi dan hanya sejauh demikian dan berdasarkan ukuran, jiwa juga rohani.

Di sisi lain, filsafat personalisme yang memberi penekanan pada kekekalan manusia yang ditemukan dalam relasi-relasi personal. Hasrat untuk kelanjutan keabadian didapatkan dalam relasi personal dengan sesama (relasi aku-engkau). Refleksi atas cinta mengatakan bahwa dalam cinta dihayati suatu keabadian, yang

\footnotetext{
${ }^{49}$ M. Sastrapratedja, Filsafat Manusia (Jakarta: Pusat Kajian Filsafat dan Manusia, 2010), 177-179.

${ }^{50}$ Baker, Antropologi Metafisik, 291.

${ }^{51}$ Ibid, 278-279.

${ }^{52}$ Baker, Antropologi Metafisik, 303.
} 
dikatakan Gabriel Marcel "Mencintai seseorang ialah dengan berkata kepadanya 'Engkau tidak akan mati'". Mencintai sesama merupakan suatu kenyataan yang bertransendensi terhadap kematian biologis dan cinta lebih kuat daripada maut. 53 Di bayangkan kematian yang di alami seorang sahabat yang mempunyai relasi personal denganku, tentunya kematian yang dialaminya tidak lantas menghilangkan dia dalam ingatanku. Relasi personal tidak mungkin mati dengan kematian biologis. Sesamaku tidak bersifat rohani saja, melainkan suatu dwitunggal jiwa dan tubuh. ${ }^{54}$

Baik kematian dari segi negatif maupun, dari kematian segi positif mengandung arti, makna dan waktu yang berbeda. Namun, secara bersama-sama menekankan sebuah keutuhan dan kesejajaran.

\section{Refleksi Metafisis}

Manusia merupakan makhluk multidimensional sekaligus paradoks. Dimensidimensi yang ada dalam diri manusia sering memunculkan sebuah pertentangan. Namun, hanya benar di dalam kesatuannya. Dimensi manusia ialah dimensi tubuh dan jiwa, materi dan spiritual, terbatas dan tak terbatas serta terikat dan bebas. Tubuh sebagai suatu kenyataan tertutup yang terikat dalam ruang dan waktu atau kenyataan yang spasial dan temporal. Sedangkan, jiwa ialah bebas dan tidak terikat dengan ruang dan waktu serta terbuka tanpa batas. Manusia adalah tertutup sekaligus terbuka, terbatas sekaligus tak terbatas, bebas sekaligus terikat. Manusia merupakan kesatuan, tetapi dalam kesatuan itu terdapat dualitas yaitu tubuh dan jiwa. Materi dan roh atau tubuh dan jiwa yang menjadikan manusia sebagai makhluk multidimensional. Suatu kesatuan namun, memiliki dua kenyataan yang saling bertentangan. Bertentangan dalam cara berada tubuh dan jiwa, namun satu dalam diri manusia.

Dikatakan manusia saat memiliki tubuh, karena tubuh menjadi cara berada manusia dalam dunia empiris. Namun, dikatakan manusia juga saat memiliki jiwa, sebab jiwa sebagai metafor kesadaran manusia yang berkekuatan spiritual. Baik mengatakan tubuh atau jiwa saja, tetap itu dianggap sebagai manusia. Namun, tidak sebagai manusia utuh 'aku'. Manusia sebagai kesatuan tubuh dan jiwa. Sebab, tubuh ialah tubuh yang di jiwai dan jiwa ialah jiwa yang di tubuhi. Ini berarti tubuh tidak bisa berada sendiri tanpa jiwa dan jiwa tidak bisa menyatakan kehendaknya tanpa tubuh. Tubuh dan jiwa berkolaborasi dalam diri manusia untuk menyatakan eksistensi manusia dalam dunia empiris. Hubungan antara tubuh-jiwa terlihat dalam kehidupan keseharian manusia, sehingga tubuh-jiwa tidak bisa dilepaskan satu dengan lain. Keduanya harus ada dan saling melengkapi dalam menyatakan eksistensi manusia.

Asal usul mengenai hakikat manusia yaitu tubuh dan jiwa yang membentuk eksistensi manusia memiliki pandangan berbeda-beda. Namun, yang pasti bahwa tubuh-

\footnotetext{
${ }^{53}$ Snijders, Antropologi Filsafat Manusia Paradoks dan Seruan, 189.

${ }^{54}$ Ibid, 49.
} 
jiwa sudah ada dimiliki manusia sejak lahirnya bahkan, sejak dari kandungan. Tubuh dan jiwa merupakan dua unsur atau hakikat yang harus dimiliki manusia untuk menampakkan eksistensinya dalam dunia empiris. Saat manusia mengalami kematian tubuh dan jiwanya akan berpisah sebagai proses atau tanda bahwa manusia benarbenar mati. Dalam kematian segi negatif, baik tubuh dan jiwa sama-sama akan mengalami kematian. Tubuh akan hancur dan jiwa lenyap. Sehingga, pandangan kematian manusia seutuhnya dengan konsep kematian dari segi negatif ialah sama. Sedangkan, dalam kematian segi positif, tubuh-jiwa yang telah mati dan lenyap mempunyai harapan untuk mendapatkan keabadian dalam proses kristalisasi. Dalam proses ini, bukan hanya jiwa melainkan tubuh juga abadi.

Dari kedua jenis kematian ini menggambarkan sebuah kesejajaran, keutuhan dan kesatuan tubuh-jiwa. Sebab, tubuh ialah tubuh yang dijiwai dan jiwa ialah tubuh yang ditubuhi. Namun, pandangan filsafat personalisme dalam relasi personal "aku-engkau" menekankan kekekalan manusia yang tidak bisa dikalahkan oleh maut dan itu ditemukan melalui cinta. Dalam cinta dihayati sesuatu yang abadi, sekalipun orang yang dicintai telah meninggal, akan tetap ada dalam pikiran dan jiwa secara utuh. Kematian biologis yang dialaminya tidak lantas membuatnya menghilang, hanya cara kehadirannya yang kini berbeda. Sehingga, baik tubuh maupun jiwa tetap ada dan tersimpan dalam relasi personal selama orang yang mengingat masih hidup.

\section{Kesimpulan}

Berdasarkan hasil analisis terhadap data yang diperoleh dari studi pustaka dan pengamatan sepintas serta hasil refleksi metafisis, ada dua hal yang ditemukan dalam penelitian ini, yaitu: Pertama, kematian manusia menurut Pengakuan Gereja Toraja ialah manusia sebagai kesatuan tubuh dan jiwa. Jiwa tidak ilahi dan tidak lebih penting dari tubuh atau sebaliknya, sehingga dalam kematian manusia, tidak hanya tubuh yang mengalami kematian tetapi jiwa juga mengalami kematian yang menghasilkan pandangan kematian seutuhnya. Sedangkan, kematian seutuhnya dalam pandangan antropologi metafisik adalah seluruh manusia yang meninggal, baik tubuh dan jiwanya serta seluruh manusia juga yang memperoleh keabadian. Manusia mati secara utuh dan hidup secara utuh. Sebab, kajian antropologi metafisik memandang manusia sebagai keutuhan tubuh dan jiwa. Dari hasil ini ditemukan, bahwa kematian seutuhnya dalam Pengakuan Gereja Toraja dengan kematian dalam pandangan antropologi metafisik ialah manusia sebagai kesatuan dan keutuhan yang tidak terpisahkan. Sehingga, memiliki kemiripan dengan kematian seutuhnya dalam Pengakuan Gereja Toraja (PGT). Kedua, melalui filsafat personalisme dalam relasi personal "aku-engkau" yang menekankan kekekalan manusia dalam relasi-relasi personal dengan sesama. Di temukan bahwa hasrat kelanjutan keabadian manusia ada dalam sebuah cinta. Cintalah yang membuat manusia tetap dapat mengingat sesamanya walaupun telah meninggal sebab, relasi personal "aku-engkau" ada. Kematian yang dialaminya, tidak dapat menghilangkannya dari hidup ini, hanya saja cara beradanya yang berbeda dan tetap sebagai keutuhan 
dalam ingatan dan relasi personal selama 'aku' masih hidup.

\section{Daftar Pustaka}

Abidin, Zainal. Filsafat Manusia. Bandung: Remaja Rosdakarya, 2011.

Arif, Oesman Arif. Dasar-Dasar Ilmu Filsafat Timur Dan Barat. Jakarta: Genta Nusantara, 2015.

Bagus, Lorens. Kamus Filsafat. Jakarta: Gramedia Pustaka Utama, n.d

Baker, Anton. Antropologi Metafisik. Yogyakarta: Kanisius, 2008.

Bertens, K. Ringkasan Filsafat. Yogyakarta: Kanisius, 2012.

Hadiwijono, Harun. Iman Kristen. Jakarta: BPK Gunung Mulia, 2009.

Hoekema, Anthony A. Manusia Ciptaan Menurut Gambar Allah. Surabaya: momentum, 2000.

Ibda, Hamidulloh. Filsafat Umum Zaman Now. Pati: Kataba Grup, 2018. Kabanga', Andarias. Manusia Mati Seutuhnya. Yogyakarta: media pressindo, 2002.

Jena, Yeremias. Wacana Tubuh Dan Kedokteran Sebuah Refleksi. Jakarta: Universitas Katolik Atma Jaya, 2019.

Kobong, Th Beberapa Catatan sebagai Pengantar Umum pada Konsultasi Pengakuan Gereja Toraja, Tangmentoe, tanggal 26-29 November 1973.

Liweri, Alo M.S. Prasangka, Konflik Dan Komunikasi AntarBudaya. Jakarta: Sejarah Kencana, 2018.

M. Sastrapratedja. Filsafat Manusia. Jakarta: Pusat Kajian Filsafat dan Manusia, 2010.

Notulen Sidang Sinode Am XVI Gereja Toraja tahun 1981.

Nurmansyah, Gunsu. Pengantar Antropologi. Bandar Lampung: Aura, 2019.

Panggalo, I.Y. Pengakuan Gereja Toraja 1981 Skripsi Minor Sarjana Teologia untuk STT INTIM Ujung Pandang: STT INTIM, 1982.

Plaiser, Jan Arie. Manusia Gambar Allah. Jakarta: BPK Gunung Mulia, 2002.

Subagyo, Andreas Bambang. Pengantar Riset Kuantitatif Dan Kualitatif. Bandung: Kalam Hidup, 2006.

Ryrie, Charles C. Teologi Dasar 1 Panduan Populer Untuk Memahami Kebenaran Alkitab. Yogyakarta: Andi, 2015.

Sihotang, Kasdin. Filsafat Manusia. Yogyakarta: Kanisius, 2009.

Sudarsono. Kamus Filsafat Dan Psikologi. Jakarta: Rineka Cipta, 1993.

Snijders, Adelbert. Antropologi Filsafat Manusia Paradoks Dan Seruan. Yogyakarta: Kanisius, 2019. 
Timo, Ebenhaizer I. Nuban. Meng-Hari-Ini-Kan Injil di Bumi Pancasila. Jakarta: BPK Gunung Mulia.

Tumanggor, Oloan Tumanggor dan Carolous Suharyanto. Pengantar Filsafat Untuk Psikologi. Yogyakarta: Kanisius, 2017.

Zulhelmi, "Metafisika Suhrawardi: Gradasi Esensi dan Kesadaran Diri," JIA: Jurnal Raden Fatah , no. 1 (Juni 2019): 102-115. 